\title{
Knowledge, science and rationality: In discussion with Wentzel van Huyssteen's earlier work
}

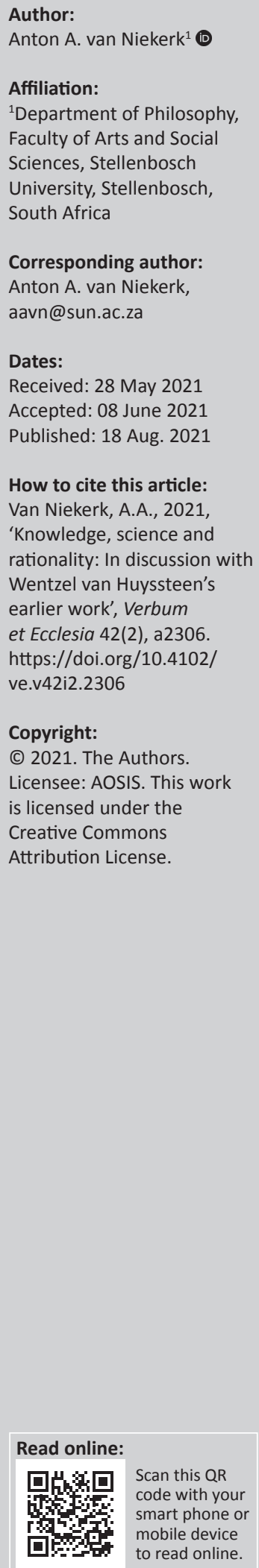

The background of this research study is the ongoing debate since the late 1980s about the question of the rationality and scientific status of theology. Wentzel van Huyssteen's seminal book Teologie as Kritiese Geloofsverantwoording has, in South Africa and abroad (after he moved to Princeton Theological Seminary), became a standard text of reference in this debate. As the book appeared, the author of this chapter has been in numerous debates with Van Huyssteen about this book. Whilst certain aspects of the book cannot but be applauded, Van Niekerk has serious questions about aspects of Van Huyssteen's work that he raises in this chapter. The method used for writing this text is conceptual analysis; no empirical study needs to be performed for this kind of contribution. The main conclusions are as follows: 1. there are notable similarities between scientific knowledge and systematic theology. 2. It is not selfevident that in case of tension between notions of rationality operative in science and theology, it is theology that necessarily has to make serious adjustments. 3. Science does not have a monopoly over the understanding and utilisation of the idea of rationality. 4 . Science is not the only correlate of truly trustworthy and reliable knowledge of reality. 5. All knowledge (including science) correlates with a variety of human interests. 6 . The notion of rationality can and often does attain a meaning specifically related to the interest-directed forms of knowledge. 7. The meaning of the notion of rationality must be broadened in a way that makes it more universally applicable in all reliable terrains of knowledge. 8. The significance of philosophical hermeneutics for our understanding of a broadened notion of rationality ought to be better explored.

Intradisciplinary and/or interdisciplinary implications: The contextual perspective of this article is the demonstration that the debate about the rationality of theology is well advanced, although far from conclusively resolved. A quite influential perspective in this debate - that of Wentzel van Huyssteen - is analysed and submitted to stringent critique. An alternative perspective is developed that deserves to be taken seriously in this debate.

Keywords: science; rationality; theology; paradigm; philosophy; metaphors; Habermas.

\section{Introduction}

The appearance of a Festschrift is a humbling experience. It is difficult to believe that Wentzel van Huyssteen, that vibrant, energetic, erudite and joyous individual who I came to know in the early 1980s is turning 80 in 2021. He took the theological establishment of South Africa by the proverbial storm with the appearance of Teologie as Kritiese Geloofsverantwoording: Teorievorming in die Sistematiese Teologie in 1986. This book was, in 1989, translated by H.F Snijders and published by Eerdmans as Theology and the Justification of Faith: Constructing Theories in Systematic Theology. (My references to this work will, unless otherwise indicated, be to the original Afrikaans version [Van Huyssteen 1986] that I will abbreviate to Teologie as Kritiese Geloofsverantwoording [TKG].)

In conclusion of an extensive review of the book that, at the time, I wrote for the South African Journal of Philosophy (Van Niekerk 1986), I declared the following (freely translated from the Afrikaans):

[T] his book elevates the discussion of philosophical theology in South Africa to a new and exciting level. As such it is pioneering work that deserves to stand noted as the point of departure for a new generation of South African theologians whose thematic consciousness will infuse a new imprint on the practice of theology in this country. (p. 96, [author's own translation])

Van Huyssteen's subsequent career has confirmed these words. His status as a philosophical theologian was confirmed by his appointment (from 1992 to 2014) in the James I McCord Chair of

Note: Special Collection: Festschrift for Wentzel van Huyssteen 
Theology and Science at Princeton Theological Seminary. One of the most seminal acknowledgements of his status in philosophico-theological circles was his invitation to offer the prestigious Gifford lectures at Oxford University in 2004 (Van Huyssteen 2005).

Besides the likes of sterling thinkers, such as Vincent Brümmer, Alan Boesak, Desmond Tutu and John de Gruchy, Van Huyssteen must be regarded as one of the most prominent theologians that this country has ever produced. What places him in a unique position vis-à-vis these other thinkers is his specific problematic related to rationality and scientific status of theology, rather than the emphasis on socio-political issues that the other mentioned thinkers (except for Brümmer) - thinkers that I all greatly admire belabor. Whilst everyone's contribution is important, and granted the actuality that political theology had in the 1980s, my guess is that Van Huyssteen's work will be studied, reflected on and criticised for a longer and more sustained period of time than the others I referred to.

In the rest of this article, I submit the main impetus of Van Huyssteen's early work (with which I am much more familiar than his work of the 1990s and later) to a critical analysis. I remain convinced that Teologie as Kritiese Geloofsverantwoording (translated as Theology and the Justification of Faith) remains, in the long run his most influential work and the basis of the programme that he construed for philosophical theology in later years. Although I have a lot of respect for and affirmation of the primary motive of Van Huyssteen's work, viz. the effort to demonstrate that rationality is not an ideal that can only be found in and reserved for science, and that a dialogue between science and religion is possible, the origins of which have not been adequately understood until his work came to the fore, it does not mean that I am in full agreement with Van Huyssteen's programme. I therefore offer the remarks of this chapter in the spirit of academic collegiality, that is, a spirit of dialogue and critical scrutiny, with the hope that new vistas for insight and intellectual progress might be explored in the process.

\section{A model of rationality for theology}

Van Huyssteen, particularly in his early work, is fundamentally interested in developing what he calls a 'model of rationality for theology'. His task, as formulated in the translated title of the book that made him famous, is to develop such a model of rationality for the sake of developing a kind of rationally motivated theology that could serve as a credible intellectual 'justification of faith'.

He is convinced that theologians who wish to, seriously and honestly, reflect on the difficult issue of the scientific and rational status of theology, are able to avoid the following two pitfalls: a sacrificium intellectus (i.e. an acknowledgement that the intellect, for this task, is inadequate and doomed to failure), or a denial of the self-identity of theology, that is, a denial of theologians' commitment to the fundamental conviction of faith that God brought forth salvation in the man Jesus of Nazareth.
In the first part of TKG, he makes the deliberate choice - a choice that will be questioned later on in this study - to argue for the cognitive status of theology in specific dialogue with a number of representatives of contemporary philosophy of science that came into prominence during the 20th century, particularly in the 1960s and 1970s. Here, I am specifically referring to figures, such as the Logical Positivists (Schlick 1974), (Ayer 1936), etc., Karl Barth (1932), Karl Popper (1963, 1968), Bartley (1964) and Kuhn (1970).

What Van Huyssteen hopes to learn from these thinkers are the epistemological criteria of good science, the complex problematic related to rationality, objectivity and truth, different interpretations of the structure of scientific theories and questions about the theoretical and practical aims of science.

Van Huyssteen's central argument in this respect entails the following claims: The logical positivists developed a conception of science that requires legitimate knowledge claims to be either tautologies (like the claims of mathematics) or empirically verifiable by recourse to facts that in a neutral, unhindered way speak for themselves. Hume's famous 'fork' thus continues to influence these thinkers very strongly. The idea that reality is knowable and can be registered 'in itself', without the mediating function of a subject that theorises, is for Van Huyssteen ideological and unaccountable. There is no possibility that theology's intellectual respectability can be upheld by its adherence to such an ideal.

In this respect, Van Huyssteen makes the interesting argument that Karl Barth's theology is also reminiscent of a kind of 'revelatory positivism'. God, for Barth, seems to be 'an objective fact of revelation' that, unsolicited, penetrates our earthly existence 'senkrecht von Oben' ('perpendicularly from above'). In the process it 'speaks for itself'; it is not mediated by the interpretative actions of a theorising subject. According to Van Huyssteen, this results in a selfconstructed, subjective representation of God despite the objectivity claims that he (Barth) wishes to construe for theology (Barth 1932).

Surprisingly, the ideas of Karl Popper also serve for Van Huyssteen as a source for the understanding of scientific theorising and conceptualising in theology. Popper promotes the idea that all scientific theories are always only provisionally valid 'pending further evidence' (Popper 1963). The rationality of science coincides with its falsifiability. The true scientist is not the person who always strives to be correct in his or her descriptions and explanations of the world but who construes theories in such a way that it is clear what kinds of observations or deductions would falsify the proposed theories. Hence, Popper's (1968) famous dictum:

$[T]$ he wrong way of science betrays itself in the craving to be right; for it is not in his possession of knowledge, of irrefutable truth that makes the man of science, but his persistent and recklessly critical quest for truth. (p. 281) 
The hero in Popper's Olympus of scientists is, therefore, Einstein, who formulated his general theory of relativity in such a way that the conditions were clearly formulated, which would, should they obtain, definitively falsify the theory. Certainty is, consequently, an ideal that the true scientist has to forfeit. A theory can at most be corroborated, that is, put to the test and, if not refuted, declared to be a theory that has 'stood up to its tests'. The origin of theories is unimportant for Popper. What is important is their rationality, that is, their testability. Said differently: what counts in the practice of science is not the context of discovery of a theory, but its context of validation (Reichenbach, as quoted by Rossouw 1990).

From William Warren Bartley, a member of Popper's 'school of critical rationalism', Van Huyssteen learns that an irrational 'retreat to commitment' (title of Bartley's best known book; Bartley 1964) is no recourse for the theologian who values the rationality of his or her theories. Bartley argues that rationality as criticizability is possible because a 'commitment to noncommitment' is logically possible. In his defence of this position, he commits the logical error of the dictatorial strategy, that is, a mode of argumentation where you cannot lose the argument and where your theory is consequently non-falsifiable contrary to what is fundamentally claimed for rationality in critical rationalism. Over and against Bartely, Van Huyssteen defends the following plausible position: 'the systematic theologian can be committed without, in the process, being methodologically definitively compromised' (TKG).

Van Huyssteen then pays admirable attention to the work of Thomas Kuhn on the paradigmatic development and structure of scientific enquiry (Kuhn 1970). Van Huyssteen - this time not surprisingly - identifies six aspects of the Kuhnian notion of the structure of scientific revolutions that he (Van Huyssteen) regards as highly relevant for the understanding of scientific theology. These points can be summarised as follows:

1. Systematic theology is always paradigmatically determined.

2. Like all scientists, the systematic theologian operates from and on the basis of a commitment.

3. Theological reflection is a group-based activity, and the theological commitment is shared by every member of the group.

4. Systematic theology, like all science, does not grow or 'develop' by accumulating and gradually adding new elements to its corpus of knowledge. It rather grows disruptively via a series of discordant revolutionary shocks that are interpreted as incommensurable paradigms.

5. Because of the paradigm shifts to which theologians are (also) submitted, they often start working on problems that they did not encounter earlier.

6. Also in systematic theology, a paradigm shift, as conceptual transformation, only happens if it occurs integrally across the entire framework of the theologian.

These are, indeed, bold claims for the actual practice of (systematic) theology. Unfortunately, Van Huyssteen does not follow up with one or two case studies to prove his point(s) in this respect.
In the second part of TKG, that is, chapters 6 and 7, he discusses the main contributions made by two German thinkers, Pannenberg (1973) and Sauter (1973), to the problematic of the scientific and theoretical status and legitimacy of theological knowledge claims. Whilst one cannot but be impressed by the depth of thought that emerges from Pannenberg's work, I personally was quite disappointed by the 'contribution' of Sauter, despite Van Huyssteen's sympathetic treatment of Sauter's work. I found it quite difficult to make much sense of, for example, Sauter's identification of what he calls the 'five foundational problems of theology' (Sauter 1971). His formulation of these five problems hardly contributes to any clarity on the issue. Sauter uses formulations, such as 'the rational limitedness of theology', 'the describability [what on earth?] of theology' and 'the relationship between history and the present: the hermeneutical problem'. My belated opinion has always been that Van Huyssteen's chapter on Sauter is the worst in his TKG and could (and should!) have been left out without any negative effect on the rest of the book.

The third part of TKG then consists of the author's own effort to develop what he calls 'a substantive model of rationality for systematic theology that wishes to understand itself as a form of critical justification of faith' ['kritiese geloofsverantwoording']. What does van Huyssteen mean by the notion of a 'model of rationality'? The answer to this question has two parts. He firstly means an argumentative discussion of the nature of theological propositions (chapter 8). Secondly, he means the identification of 'criteria for a criticalrealist rationality model for systematic theology' (chapter 9).

With reference to the nature of theological claims, Van Huyssteen then discusses aspects such as the origin of theological propositions. In this respect, he pays considerable attention (in TKG as well as in subsequent works) to religious experience, together with the language of faith that emanates from that experience, as the origin of theological knowledge claims. With reference to the origin of theological claims, he also refers quite extensively to the metaphors of faith. Metaphors, which abound in the life of faith, have epistemological status, as has been extensively argued by thinkers, such as Black (1962), Barbour (1976), TeSelle (1975), Ricoeur $(1973,1978)$ and many others (see also Van Niekerk 1983). Metaphors, as Ricoeur succinctly demonstrates and argues, describes the transcendent dimension of reality which it also identifies (see also King 1974). Theological language is thus for Van Huyssteen cognitive in the sense that it 'refers to something', as well as in the way in which dominant thought models (Metaphors with staying power - McFague 1983) influence the formation of theological concept.

The three criteria that Van Huyssteen distinguishes for a critical-realist model of rationality in systematic theology are as follows:

1. The first is theological claims' relatedness to reality ('werklikheidsbetrokkenheid') as contextuality. What exactly he means by this is not entirely clear. He does 
nevertheless eventually distinguish three 'contexts' as the 'space within which the theologian must preferably articulate his or her claims about God'. These are religious experiences, the church and theological reflection itself.

2. The second criterion that Van Huyssteen distinguishes includes the critical and problem-solving ability of theological statements. In this context, he asks questions such as what can actually, within the sphere of systematic theology, qualify as a 'problem'? Drawing on the work of Larry Laudan, he distinguishes between empirical and conceptual problems in theology. He consequently identifies the Bible, the tradition of theological reflection and the 'context of contemporary thinking' as the criteria on which we draw to evaluate the solution of religious issues that we wish to provide via the interpreting redescription and contextualising of the content of our faith. This evaluation enables us to identify such 'solutions' as credible, less credible or bad theories.

3. The third and last criterion that Van Huyssteen identifies includes the designing and progressive nature of theological claims'. This has to do with the 'problemsolving model' by means of which we try, as effectively as possible, to solve the problems of theology and thus unlock meaning maximally within the context of a specific problem, which could be indicated as the essence of progress in systematic theology. Van Huyssteen insists that, also in theology, theories are chosen because they prove to be better problem solvers than their predecessors. Drawing on Popper, Van Huyssteen accepts that theological theories must be regarded as tentative and provisional. We must at all costs prevent them from becoming 'ideologized' as if they are absolutely and infinitely 'true'.

\section{(Natural) science as the paradigm for rationality in theology?}

As stated earlier, one cannot but admire the remarkable work that Van Huyssteen has performed in the field of philosophical theology, with special reference to his efforts to develop what he calls a 'model of rationality for systematic theology'. However, I am personally not convinced by all aspects of his programme. This particularly pertains to the way in which he, when seeking for a model of rationality that can be successfully applied to systematic theology, insists on drawing only on the work of philosophers of science (particularly the logical positivists, Popper, Bartley, Kuhn and others) whose intellectual contributions in the field of the philosophy of science are by and large confined to the natural sciences.

One can fully understand Van Huyssteen's motives in this regard. It is clear from the outset that he (indeed with some justification) fears, particularly in the context of the secularism of our times, a descent of systematic theology into the abyss of sustained reproaches of irrationality, subjectivism and fundamentalism. What Van Huyssteen seemingly fears more than anything else is the rejection of theology as a kind of 'gutter' activity that is no longer taken seriously in intellectual circles. He is in this respect no doubt influenced by the sharp criticisms that are meted out to theology from such disparate ranks as Albert (1985), who denounces both theology and hermeneutics with his argument that these activities cannot resolve the 'Münchhausen trilemma', to Richard Dawkins, who denounces all claims to rational religious belief because of its (according to Dawkins) palpable lack of supporting evidence (Dawkins 2003; see also Van Niekerk 2014).

Before I come to my criticisms of Van Huyssteen's contribution, let me re-assert that his appreciation and utilisation of, in particular, the work of the post-empiricist philosophy of science (Kuhn in particular) for facilitating his search for a model of rationality for theology, yield insights that I share and could strongly commend. I regard the following as valuable insights in this respect, even though my formulation of these insights may differ slightly from that of Van Huyssteen:

- The recognition of the role of tradition and authority in the acquisition of all - thus including theological - knowledge.

- The acknowledgement of the inevitability of theoretical frames of reference - transmitted historically - that condition the possibilities and even the contents of perceptions.

- The recognition of the role of language in the acquisition of knowledge - language as the key to and the medium of understanding.

- The acknowledgement of the pivotal role of historical circumstances, influences, preferences and even prejudices, as well as personal and professional aspirations, in the generation of knowledge claims (Bloor 1983).

My main criticism of Van Huyssteen's TKG has to do with the exulted status, which he affords to (natural) science, in general, and specifically in the development of his 'rationality model for systematic theology'. Although Van Huyssteen does not go as far as understanding the terms 'science' and 'rationality' as synonyms, it is quite clear from the discussion provided in the previous paragraph that whenever Van Huyssteen raises the issue of rationality, natural science provides the paradigm for his suggested notion of rationality. The justification of the rational status of any - including theology's - knowledge is not the same as the justification of the scientific status of knowledge claims. I stress that science (in the sense of experimental physical science) has no monopoly of that which we can meaningfully say about the world and about the meanings of our lives in the world. Put differently, when it comes to justifying the rational character of a discipline such as systematic theology, our only or most important recourse is certainly to natural and applied science. That kind of justification requires sensitivity to a broader understanding of reason and rationality.

It can certainly not be denied that (the natural and applied) sciences have in incomparable ways transformed the world for us into an accessible and habitable environment. I am sincerely convinced of the way in which, partly using science and technology, the world in our time has become a cleaner, 
more prosperous, safer and healthier place than any other pre-scientific culture - indeed, than at any stage before the advent of the 20th century. (Our recent experience with Covid 19 does dampen the conviction with which I normally write a sentence like the previous one - somewhat!). The darker side of the effects of our scientific culture - Auschwitz, Hiroshima and Chernobyl - must, however, also not be forgotten. Science and technology have meant much for our world, but have with time also caused enormous damage. The damage is, however, in my opinion, not the result of something inherently wicked in science and technology, but rather a result of the irresponsible application and use of science and technology.

Nevertheless, everything that there is to say about what is of importance to us as human beings, does not lie exclusively in what science can teach us. Mankind is much more than just a seeker of theoretical insights and material provisions. (Wo) man is also involved in a persistent search for meaning. As such, (wo)man asks questions which make science uncomfortable, because it cannot or will not answer these questions: where do we come from, what is our destiny and what is the meaning of human life in the world? We often find that, particularly within certain philosophical traditions, the legitimacy of the latter questions is queried. Amongst others - like Dawkins and Dennett - the impression is created that science, and science alone, can answer these questions (Dawkins 2003; Dennett 1995). Because the answers to these questions appear to be so hard to find, one's right to ask these questions at all is often also denied. To contend that we may not ask questions about our origin or destiny or about the meaning of life is to expect from us that we stop being human. That is too much to ask. Because science is uncomfortable with such questions, it does not mean that these questions are unimportant. They seem to me like questions that must feature in the dimension of life which we call faith - that upon which theology reflects (fides quaerens intellectum, as St Anselm formulated it in the 12th century).

Van Huyssteen's tendency to elevate natural and applied science to the paradigm for knowledge and rationality, is, in my opinion, an indication that logical positivism and Popper have a very strong influence on him. The problem starts with the quite select group of thinkers with whom he chooses to interact. It is, indeed, possible that knowledge claims - also in theology - could have rational status without necessarily commanding scientific status - at least in the sense in which Van Huyssteen uses the latter term. As I have argued, the (natural) sciences have no monopoly over acceptable procedures in this regard, and therefore, no monopoly over the formulation of the rules for the legitimate use of 'rational' as qualification of knowledge claims. There are other highly acclaimed philosophical traditions that have argued extensively and impressively for the same point. The names of thinkers such as those from the traditions of phenomenology (Husserl, Merleau-Ponty, Kwant and Luijpen) and philosophical hermeneutics (Gadamer, Habermas and Taylor) come to the fore in this regard.
Van Huyssteen's contribution might well have profited from more attention to these traditions and thinkers. Space does not allow me to explore the ideas of the named thinkers to the full for the purposes of this article. In the following section, I, however, show how the thinking of the early Habermas - as an excellent example of what I have in mind - is of pivotal importance to justify the insight that there are, indeed, different forms of knowledge emanating from different interests, on the basis of which we make sense of the world. In the concluding section, I apply a few of these insights to Van Huyssteen's programme.

\section{Different interests; different kinds of knowledge}

Consequently, I wish to draw on some insights of the German philosopher Jürgen Habermas, foremost exponent of Critical Theory and Critical Hermeneutics. In his book Knowledge and Human Interests (Habermas 1972), Habermas argues forcefully in favour of the idea - widely shared by proponents of post-empiricist philosophers of science (particularly Kuhn) - that knowledge acquisition is always driven by human interests. Secondly, he approaches the question of what the original purpose and end results of knowledge acquisition are from a fundamentally anthropological angle.

For Habermas, our most basic traits as a species emerge from two original human activities with which we are all engaged, namely, labour and communication. In turn, labour and communication as species-typical activities are the outcome of two fundamental interests that we adopt towards our world: the so-called technical and practical interests. (A third interest, namely emancipation, to which I will refer later, is eventually also added by Habermas). Labour - the creative human impingement on our environment for the sake of bodily survival - is the activity that flows from the technical interest. By the latter, Habermas means the interest that all of us have in deciphering the regularities that underlie and govern our natural environment, in order to enable us to understand, predict and apply these regularities for the sake of our biological survival.

This is what happens in science-based technologies. Put differently, the technical interest refers to a striving towards the attainment of control over the forces and processes in our natural environment - a control that enables us to survive biologically in this environment and to adapt or organise it optimally for our mutual benefit. The empirical-analytical sciences (by which Habermas means the natural and applied sciences) are the systematic formation of the execution of the technical interest.

However, humankind is more than mere labouring animals. Man or woman does not realise his or her identity only on the basis of the technical interest. We, as a species, are humans on another basis than merely that of labour and technology; we do not 'live of bread alone'. The other manner of existence is, for Habermas, communication, by which he means the search 
for meaning, which is the outcome of the second interest on the basis of which we produce culture. Habermas calls this second interest the practical interest, that is, the interest that we all have, based on the continuous intersubjective dialogue, to come to a mutual understanding or consensus about the kind of life that is worth living and the values that ought to inform that life. In view of this second ideal or interest, humankind creates symbolic forms (i.e. works of art, ideas, texts, artefacts, values, political and social systems, ideologies, etc.) that are expressions of the ways in which we, in deliberation and collaboration with fellow human beings, make sense of our world and ourselves.

For Habermas, the 'historical hermeneutical' (we could also say the human or social) sciences are the systematic formation of the practical interest, that is, of the second, equally important and unavoidable way in which we are what we are and in which we realise our particular identity as a species.

These historical-hermeneutical or social sciences (such as economics, sociology and political science) could and often produce nomological knowledge (i.e. knowledge governed by identifiable and predictable regularities or 'laws', nomoi), of which scientific knowledge is the prototype. Habermas, however, as indicated earlier, also identifies a third interest from which knowledge emerges - albeit a markedly different kind of knowledge. He calls it the emancipatory interest. This is the interest undergirding truly critical social sciences. This is the type of critical theory that often acts as the critique of ideology, an epistemic enterprise that identifies and transcends 'frozen relationships of dependence that can in principle be transformed' (Habermas 1972).

Charles Taylor is another philosopher who insists on the 'disanalogy' between theory formation in the empiricalanalytical and critical-social sciences. The most important difference between them relates to the fact that, in the case of the social sciences, we normally have a common-sense understanding of what it is that we try to elucidate theoretically. To quote Taylor (1985):

[T] here is always a pre-theoretical understanding of what is going on among the members of a society, which is formulated in the definitions of self and other which are involved in the institutions and practices of that society. (p. 93)

Examples of these include decision-making by majority vote, the institution of hiring employees on the basis of free contractual arrangements, the nationalistic basis of international relations and conceptions of the family as the core unit of social institutions.

(For the previous section I have partly drawn on work that I have carried out elsewhere; see Van Niekerk 2019).

\section{Application to Van Huyssteen's work}

By this time, it is hopefully clear what the relevance of the analysis in the previous paragraph is for our evaluation of Van Huyssteen's project. Van Huyssteen searches for a model of rationality for systematic theology that meets the criteria of rationality that one by and large associates with the natural and applied sciences. Hence, the fact that Van Huyssteen pays a great deal of attention to rationality conceptions that emanate from logical positivism and Popper. In his later work, post-empiricist philosophy, as well as postmodernism (cf. Van Huyssteen 1999), gains in eminence as his sources for this enterprise. However, I hope to have shown that there is an avenue of thinking about legitimate, and hence, rationally justifiable knowledge that Van Huyssteen has, up till now, not explored adequately.

The reason why Van Huyssteen has not explored the thinking of Habermas and Taylor, as discussed above, is in all probability the fact that he is notably hesitant to acknowledge, with someone like Habermas, that the natural and applied sciences (for these Habermas uses the phrase 'empiricalanalytical sciences') are not the only kinds of knowledge that we are to take seriously to understand and influence the world. Again, Van Huyssteen is correct in his admiration for the natural sciences, the outcome of which has resulted in our accumulation of unprecedented power over nature. Systematic theology, which in my opinion is, indeed, a fully legitimate kind of knowledge, need not forfeit its aspiration for cognitive respectability in order to persistently play the game of the outcome of the technical interest. The technical interest, as I, following Habermas, tried to show, is that interest in gaining knowledge that enables us to identify, predict and utilise the regularities of nature, thereby contributing significantly to our biological survival as a species. Why would systematic theology hope to justify its intellectual grasp of the world via methodologies that engage with the world in this manner?

The knowledge that emanates from the technical interest is not the only kind of knowledge by means of which we live meaningfully in the world. It is in a sense surprising that Van Huyssteen does not acknowledge this of his own accord. The acknowledgement of different kinds of knowledge is a pivotal insight of hermeneutic philosophy, driven by the recognition that the 'object domain' of the social sciences is always value-laden and requires interpretation rather than explanation as its mode of acquiring knowledge. By the latter, I am not claiming that explanation and interpretation or understanding constitute an always mutually exclusive dichotomy. I have carried out work myself that criticises the idea of such a stark and persistent dichotomy (Van Niekerk 1989). However, denying that the notable differences between explanation and understanding can consistently be upheld does not imply that the opposition between explanation and interpretation as distinct modes of knowledge has to be denied from the outset.

In this regard, Ricoeur has a helpful idea. He suggests, when writing about the sustainability of the dichotomy, that it seems possible to reconcile explanation and interpretation in the sense of situating them along what he calls 'a unique hermeneutical arc', thereby integrating the seemingly opposed attitudes of explanation and understanding within 
an overall conception of 'reading as the recovery of meaning' (Ricoeur 1981). The notion of a 'hermeneutical arc' suggests that the two modes of knowing the world are indisputably separate or distinct, just as the outer ends of an arc are distinct, but at the same time conjoined and therefore inseparable.

Howsoever interesting these ideas may be, they do not alter or diminish Habermas' claims that the practical interest yields a different kind of knowledge with, by implication, a different understanding of the notion of rationality. We do not only live for the sake of bread - important as the latter indeed is - or for the sake of the power that knowledge and technology place in our hands. The practical interest is the interest that we have to, in mutual dialogue with fellow human beings, deliberate about the kind of life that it is worth to pursue and to live. This relates to the world of values, ideas and concepts that we find the most useful and illuminating to make sense of our lives. The notion of 'sense' or 'meaning' refers to that we find the most valuable, relevant and important in our lives; those concerns for which one sometimes (such as Nelson Mandela in his famous dock address) is prepared to live, but, if necessary, one is also prepared to die. There are surely powerful arguments for the values and ideas that we pursue from the perspective of the practical interest, but the 'rationality' in terms of which such values and ideas are motivated, is not a set of criteria or the application of a methodology that notably imitates the knowledge stemming from the technical interest.

With regards to Van Huyssteen's work, there seems to be a further problem as far as his programme is concerned. He claims that he is not only in search of a model of rationality for systematic theology but he also asserts that he, as the title of the last chapter suggests, is in search of formulating 'criteria for a rationality model of systematic theology'. I am not at all sure that I understand what is being meant or claimed here. Is a 'rationality model' not itself a view in which criteria are stipulated for the rational status of knowledge claims (e.g. the demand of falsifiability in critical rationalism)? If, in terms of Van Huyssteen's earlier mentioned enterprise, the search is for 'criteria for a rationality model for theology', are we, with Van Huyssteen, called upon to identify criteria for views that themselves formulate criteria for acceptable knowledge claims? If so, how much sense can be made of this?

Van Huyssteen himself is not clear on this. If his intention is to find criteria for the rationality of theology that can be understood in a way that is analogous to the rationality of science, we are back at the first problem.

The question in this respect is simply: if the procedures for the legitimisation of knowledge claims in the empirical sciences and in theology seemingly differ considerably, why must it unquestioningly follow that theology is 'irrational', as Albert and Bartley both, indeed, accuse it of. It is not selfevident that such a difference compels the theologian to develop a model of rationality that is adapted to the empirical sciences, as Van Huyssteen seemingly wishes to do. Does the onus in such a case not rather rest on the empirical scientist to ask him or herself how his or her one-sided rationality model is adequate for dealing with the full spectrum of cognitive claims that are characteristic of the full diversity of human intellectual activities. This 'full spectrum' particularly refers to what has earlier been referred to as the correlate of the practical and emancipatory interests that yield the historicalhermeneutical as well as the critical sciences.

Van Huyssteen, it seems to me, yields much too easily to the annexation of the qualification 'rational' by philosophers of (natural and applied) sciences. The way out of this impasse is much rather the utilisation of what Merleau-Ponty (1972) calls the raison élargie, that is, a broadened notion of rationality that is able to accommodate the intellectual selfunderstanding and activities of both scientists and theologians. The rational status of theology can then be so justified without being overly concerned about the alleged 'scientific status' of theology. Theology, as far as I am concerned, is not a science in the sense in which that epithet is accorded to physics, chemistry, sociology or psychology. That does not in the least mean or imply that theology is not also a legitimate intellectual discipline, in which rationally accountable knowledge claims can be made.

\section{Conclusion: A hermeneutical notion of rationality}

Van Huyssteen's model of rationality for systematic theology has been analysed and criticised from a variety of perspectives in this study. That an intellectual programme, such as the one that he has so admirably developed, generates critique is no surprise. It is the mark of great erudition, originality and appreciation that work of this nature has been taken so seriously, not only by me but also by a host of critics all over the world.

As far as I am concerned, the question may well be asked what I foresee as an alternative to Van Huyssteen's work. The scope of this study unfortunately will and does not allow me to work that out in detail. The most that I can do is to revisit key insights and identify a few key markers to bear in mind whenever anybody undertakes to take the Van Huyssteen programme further.

In summary, the following points are worth to be noted carefully:

1. There are notable similarities between scientific knowledge and systematic theology. Van Huyssteen deserves much credit for identifying and pointing this out.

2. It is not self-evident that in case of tension between notions of rationality operative in science and theology, it is theology that necessarily has to make serious adjustments.

3. Science does not have a monopoly over the understanding and utilisation of the idea of rationality.

4. Science is not the only correlate of truly trustworthy and reliable knowledge of reality. 
5. All knowledge (including science) correlates with a variety of human interests.

6. The notion of rationality can and often does attain a meaning specifically related to the interest-directed forms of knowledge.

7. The meaning of the notion of rationality, if it is to continue to play a significant role in epistemology, must be broadened in a way that makes it more universally applicable in all reliable terrains of knowledge.

8. The significance of philosophical hermeneutics for our understanding of a broadened notion of rationality ought to be better explored.

Let me conclude by making a few remarks about the last point of this list. As stated, the great benefit of a hermeneutical notion of rationality is that it (can) broaden(s) the meaning of the concept 'rationality/reason' and makes it more universally applicable. A correct understanding of rationality reflects a notion of reason that is sensitive to the role and significance of tradition in human knowledge and experience. Reason operates and grows in the traditions by and in which we live. At the same time, reason must at all costs not prohibit the identification and utilisation of the possibility of and criteria for critique.

The notions of reason and rationality that I have in mind, are sensitive to the differences between traditions and life forms, without in the process excluding a rational comparison between these life forms. It is a notion of reason that makes us conscious of the intimate connections between explanation and understanding, as well as of the role that the exertion of healthy judgement (cf. Brown 1988 for his 'judgement model of rationality') could play in the rational comparison of life forms.

As this is crucial for the human sciences, eventually it is a notion of reason that is guided by the conviction that the study of alien phenomena and cultures will facilitate a dialogue or dialectic that will lead us to a deeper, more critical understanding of the life forms of our own and alien cultures and prejudices.

The core of this notion of reason is not to be enclosed in or confined to self-sufficient frameworks, but the openness of language, experience and understanding. Only in this way we will be able to become emancipated from an ethnocentric, arrogant and potentially totalitarian absolutism but also from a subjectivist, self-undermining and potentially anarchist relativism (Van Niekerk 1992).

\section{Acknowledgements Competing interests}

The author declares that he has no financial or personal relationships that may have inappropriately influenced him in writing this article.

\section{Author's contributions}

A.a.V.N. is the sole author of this article.

\section{Ethical considerations}

This article followed all ethical standards for research without any direct contact with human or animal subjects.

\section{Funding information}

This research received no specific grant from any funding agency in the public, commercial or not-for-profit sectors.

\section{Data availability}

Data sharing is not applicable to this article as no new data were created or analysed in this study.

\section{Disclaimer}

The views and opinions expressed in this article are those of the author and do not necessarily reflect the official policy or position of any affiliated agency of the author.

\section{References}

Albert, H., 1985, Treatise on critical reason, Princeton University Press, Princeton, NJ. Ayer, A.J., 1936, Language, truth and logic, Pelican Books, Harmondsworth. Barbour, I., 1976, Myths, models and paradigms, Harper \& Row, New York, NY. Barth, K., 1932, Kirchliche Dogmatik 1/1, EVZ Verlag, München. Bartley, W.W., 1964, The retreat to commitment, Chatto \& Windus, London. Black, M., 1962, Models and metaphors, Cornell University Press, Ithaca, NY. Bloor, D., 1983, A social theory of knowledge, Macmillan, London. Brown, H.I., 1988, Rationality, Routledge, London.

Dawkins, R., 2003, A devil's chaplain, Houghton Mifflin, Boston, MA.

Dennett, D., 1995, Darwin's dangerous idea: Evolution and the meaning of life, Simon \& Schuster, New York, NY.

Habermas, J., 1972, Knowledge and human interests, 2nd edn., Heinemann, London. King, R.H., 1974, The meaning of God, SCM Press, London.

Kuhn, T., 1970, The structure of scientific revolutions, 2nd edn., University of Chicago Press, Chicago, IL.

McFague, S., 1983, Metaphorical theology: Models of God in religious language, SCM Press, London.

Merleau-Ponty, M., 1962, Phenomenology of perception, Routledge \& Kegan Paul, London.

Pannenberg, W., 1973, Wissenschaftestheorie und Theologie, Suhrkamp, Frankfurt am Main.

Popper, K.R., 1963, Conjectures and refutations, Routledge \& Kegan Paul, London. Popper, K.R., 1968, The logic of scientific discovery, Hutchinson, London.

Ricoeur, P., 1973, 'Creativity in language: Word, polysemy, metaphor', Philosophy Today, pp. 97-111, Summer.

Ricoeur, P, 1978, The rule of metaphor, Routledge \& Kegan Paul, London.

Ricoeur, P., 1981, Hermeneutics and the human sciences, Cambridge University Press, Cambridge.

Rossouw, H.W., 1990, Wetenskap, interpretasie, wysheid, Universiteit van Port Elizabeth Seminare, Lesings en Simposiums B7, Port Elizabeth.

Sauter, G., 1971, 'Theologie als Wissenschaft, Historisch-Systematisch Einleitung', in G. Sauter (ed.), Theologie als Wissenschaft Theologische Bucherei, no. 43, Chr. Kaiser, München.

Sauter, G., 1973, Wissenschafteoretisch Kritik der Theologie. Die Theologie und die neuere wissenschaftstheoretishe Discussion, Chr.Kaiser, München.

Schlick, M., 1974, General theory of knowledge, Springer, Amsterdam.

Taylor, C., 1985, Philosophy and the human sciences, Cambridge University Press, Cambridge.

TeSelle, S.M., 1975, Speaking in parables, Fortress Press, Philadelphia, PA.

Van Huyssteen, W., 1986, Teologie as kritiese geloofsverantwoording, Human Sciences Research Council, Pretoria.

Van Huyssteen, W., 1989, Theology and the justification of faith, Eerdmans, Grand Rapids, MI.

Van Huyssteen, W., 1999, The shaping of rationality, Eerdmans, Grand Rapids, MI.

Van Huyssteen, W., 2005, Alone in the world? Human uniqueness in science and technology, Eerdmans, Grand Rapids, MI. 
Van Niekerk, A.A., 1983, 'Analogie en teologie. 'n Krities-wysgerige ondersoek van die funksie van analogie-teorieë omtrent teologiese taalgebruik', Unpublished PhD thesis, University of Stellenbosch.

Van Niekerk, A.A., 1986, 'Book review of Teologie as kritiese geloofsverantwoording (by Wentzel van Huyssteen)', South African Journal of Philosophy 5, 3.

Van Niekerk, A.A., 1989, 'Beyond the erklären-verstehen dichotomy', South African Journal of Philosophy 8 (3-4), 198-213.
Van Niekerk, A.A., 1992, Rasionaliteit en relativisme: Op soek na 'n rasionaliteitsmodel vir die menswetenskappe, Council for Human and Scientific Research, Pretoria.

Van Niekerk, A.A., 2014, Geloof sonder sekerhede, Lux Verbi, Cape Town.

Van Niekerk, A.A., 2019, "Is "decolonisation" a legitimate and appropriate value in biomedical research and teaching?', South African Journal of Bioethics and Law 12(1), 4-7. https://doi.org/10.7196/SAJBL.2019.v12i1.652 